\title{
Circumcision and prevention of HIV and AIDS in Zimbabwe: Male genital cutting as a religio-cultural rite
}

\begin{tabular}{|c|c|}
\hline $\begin{array}{l}\text { Author: } \\
\text { Temba T. Rugv }\end{array}$ & \\
\hline Affiliation: & \\
\hline $\begin{array}{l}{ }^{1} \text { Department } \\
\text { Testament Stu } \\
\text { of Pretoria, So }\end{array}$ & $\begin{array}{l}\text { f Old } \\
\text { dies, University } \\
\text { uth Africa }\end{array}$ \\
\hline $\begin{array}{l}\text { Research Proj } \\
\text { Project Leade } \\
\text { A. Groenewal } \\
\text { Project Numb }\end{array}$ & $\begin{array}{l}\text { ect Details: } \\
\text { r: } \\
\text { er: } 02428024\end{array}$ \\
\hline $\begin{array}{l}\text { Description: } \\
\text { Dr Rugwij is p } \\
\text { the research } \\
\text { 'Exegesis and } \\
\text { of Isaiah', dire } \\
\text { Prof. Dr Alpho } \\
\text { Groenewald, } \\
\text { of Old Testam } \\
\text { Faculty of The } \\
\text { Religion, Univ } \\
\text { Pretoria. }\end{array}$ & $\begin{array}{l}\text { articipating in } \\
\text { roject, } \\
\text { the Theology } \\
\text { cted by } \\
\text { nso } \\
\text { eepartment } \\
\text { ent Studies, } \\
\text { ology and } \\
\text { ersity of }\end{array}$ \\
\hline $\begin{array}{l}\text { Correspondin } \\
\text { Temba Rugwij } \\
\text { rugwiji1964@ }\end{array}$ & $\begin{array}{l}\text { g author: } \\
\text { i, } \\
\text { gmail.com }\end{array}$ \\
\hline $\begin{array}{l}\text { Dates: } \\
\text { Received: } 13 \\
\text { Accepted: } 23 \\
\text { Published: } 26\end{array}$ & $\begin{array}{l}\text { tct. } 2017 \\
\text { Mar. } 2018 \\
\text { July } 2018\end{array}$ \\
\hline $\begin{array}{l}\text { How to cite th } \\
\text { Rugwiji, T.T., 2 } \\
\text { 'Circumcision } \\
\text { of HIV and AID } \\
\text { Male genital c } \\
\text { religio-cultura } \\
\text { Teologiese Stu } \\
\text { Theological St } \\
\text { 4848. https:// } \\
10.4102 / \text { hts.v }\end{array}$ & $\begin{array}{l}\text { is article: } \\
18, \\
\text { ind prevention } \\
\text { S in Zimbabwe: } \\
\text { dtting as a } \\
\text { rite', HTS } \\
\text { dies/ } \\
\text { dies } 74(1) \text {, } \\
\text { loi.org/ } \\
4 i 1.4848\end{array}$ \\
\hline $\begin{array}{l}\text { Copyright: } \\
\text { (c) 2018. The } \\
\text { Licensee: AOS } \\
\text { is licensed un } \\
\text { Creative Comr } \\
\text { Attribution Lic }\end{array}$ & $\begin{array}{l}\text { uthors. } \\
\text { S. This work } \\
\text { ler the } \\
\text { nons } \\
\text { ense. }\end{array}$ \\
\hline Read online: & \\
\hline 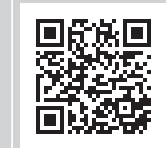 & $\begin{array}{l}\text { Scan this QR } \\
\text { code with your } \\
\text { smart phone or } \\
\text { mobile device } \\
\text { to read online. }\end{array}$ \\
\hline
\end{tabular}

Circumcision originated from ancient religious (biblical) and cultural societies. Study has shown that in both the biblical (Israelite) context and among the Karanga people in Zimbabwe circumcision emerged as a rite of passage for a boy child's entry into manhood. Modern societies promulgate circumcision as a preventive method against HIV and AIDS. The present study argues that circumcision tends to promote irresponsible sexual behaviour and trivialises the sacredness of sex. (1) To safeguard societies against the belief that circumcision prevents HIV and AIDS. (2) To sensitise societies that abstinence and condom usage will serve as preventive methods against HIV and AIDS. The study utilises two complimentary methods: (1) comparative literary method which examines both biblical and cultural initiation procedures and (2) qualitative research method in which an interview forms part of the data pool. The potential of a scientific contribution towards transforming both the mind and lifestyle can be guaranteed. The number of individuals opting to be circumcised will decline, and abstinence and condom usage should be promoted towards the prevention of HIV and AIDS. In both ancient Israel and among the Karanga people of Zimbabwe, circumcision was performed as a religious and cultural procedure. In both contexts circumcision was regarded as a rite of passage to prepare a boy child for entry into manhood. The article argued that circumcision does not prevent HIV and AIDS. To the contrary, circumcision tends to endorse promiscuity and unprotected sex, with a potential of increasing HIV and AIDS prevalence.

\section{Introduction}

When Fortune Sibanda noted that the world over, HIV and AIDS continues to ruffle feathers among different nations, particularly those in sub-Saharan Africa' (2013:1), he elaborately adds his contribution to numerous existing literature on the pandemonium caused by the virus. In response to the HIV and AIDS scourge, the World Health Organisation (WHO) (2007) 'had recommended circumcision as part of a comprehensive programme for preventing HIV transmission in areas with high endemic rates'. According to the American Academy of Pediatrics (AAP) (2012:756), male genital cutting (MGC) 'consists of surgical removal of some or all of the foreskin (or prepuce) from a penis'. Taddio et al. (1997:599-603) admit that MGC is a traumatic operation in which there is the loss of a functional body part (Wiswell 1988:444-446). Although there is no consensus among scholars, it is held by some section of the Zimbabwean society that MGC can be used as a preventive method against HIV and AIDS. However, the present discourse critiques this claim as a myth, while in the final analysis recommending alternatives such as abstinence and condom usage as remedial options towards preventing the transmission of the epidemic. This study also attempts to demonstrate that HIV and AIDS are exacerbated by poverty. In the final analysis, the essay recommends some alternatives towards reducing HIV and AIDS prevalence in Zimbabwe.

\section{Methodology}

Three main methods have informed the present discourse. Firstly, the study utilises a comparative literary approach that comprises exegesis and theological reflection (Papu \& Verster 2006:179). With that approach in mind, both biblical and cultural initiation practices are employed simultaneously. For example, a recent study by Ntozakhe Cecula, ${ }^{1}$ which touched on circumcision in view of Israel's election and God's covenant, also informed this article from a different yet University, South Africa, 04-09 September 2016. 
complementing angle. Secondly, qualitative research method also occupies an equally important portion in this study in which personal interviews and observations constitute part of the data pool. The choice of a qualitative research method has been motivated by the fact that local communities are living libraries ${ }^{2}$ because societies living in a particular demographic location have invaluable information about cultures and traditional practices present in that locality. For instance, personal interview and conversation on circumcision with one Misheck Dzichauya (pers. comm., 26 August 2016) ${ }^{3}$ yielded positive results for this research. Thirdly, secondary sources (e.g. Tsodzo 2007) also informed the present investigation significantly.

\section{Biblical (religious) view of male genital cutting}

Glass's (1999:17) study explicates that in ancient Mesopotamia, circumcision was already known. To a large extent, some of the people mentioned in the Book of Jeremiah (9:24-25) and some Egyptian Pharaohs are known to have been circumcised. De Vaux (1978:287) also comments that: 'A 3500-year-old ivory engraving found in Megiddo depicts circumcised men, believed to have been Canaanites'. Following up on both Glass's opinion and De Vaux's opinion above, Mwashambwa et al (2013:1) also admits that: 'The earliest evidence of male circumcision was discovered in Egyptian tombs aged more than 4000 years'. Meade (2016) opines that: 'The biblical text first mentions circumcision in Genesis 17 ...' (p. 35), which picks up the view that Goldingay (2000) had earlier on advanced in the following statement:

In the account of its origin in Genesis 17, God simply tells Abraham that circumcision is required, and the narrative relates its immediate application to Abraham's family and household (in 21:4 we are later assured that Isaac was also circumcised). It is clear that circumcision is to be an indispensable mark of being a (male) member of the people of promise. (cf. Ex 12:44, 48; Lev 12:3) (p. 3)

Rugwiji's (2014) recent study also reiterated that: 'Male circumcision in the Bible was commanded to Abraham as a sign of keeping the covenant with Yahweh' (Gn 12:10-14). Hence, Goldingay remarks that: 'Most of the signs of a covenant can apply to everyone, but circumcision (at least this particular rite of circumcision) applies only to males' (2000:3). Ntozakhe Cecula has also added his voice to the circumcision discourse in relation to the covenant. Cecula (2016) discusses MGC in view of God's election of and covenant with Israel. Being in covenant with the Holy God, Israel also became a holy people. As a result of God's

2.Claude Mararike. Bottom-up approaches and organic program development fundamentals. Class Lecture, University of Zimbabwe, 2010.

3.Misheck Dzichauya is a researcher with the Zimbabwe Open University (ZOU). He hails from the Mukandapi Village under sabhuku (headman) Mazivisa in rural Shurugwi northwest of Gweru, the capital of the Midlands Province in Zimbabwe. On 26 August 2016, I had a fruitful discussion with Dzichauya at ZOU offices in Harare, Zimbabwe. Dzichauya's invaluable perspectives on cultural circumcision among the Karanga community of the tribe of Mukandapi assisted a great deal in reformulating and developing the present discourse. His contribution is highly
appreciated. covenant, asserts Cecula, circumcision was instituted. Rugwiji (2014) engages in a dialogue with the following question: 'Why were Jewish women not circumcised?' In response, Rugwiji explains by stating that: 'The male patriarchal nature of the Jewish tradition could be one of the reasons why only males were circumcised'. Rugwiji further states that 'the rite of circumcision was performed on Jewish males only as an initiation into "manhood" as well as to confirm inclusion in a devout Jewish society'. Plaskow (1991:82-84) concurs that the patriarchal society of ancient biblical times regarded women as being outside God's plan for the 'salvation' of the world. In addition, Plaskow further writes that 'women represent Israel's unredeemed flesh' (1991:82-84; see Goldingay 2000:3). Plaskow's affirmation is followed up by Hoffman (1996:2) who remarked that: 'Circumcision was a rite of masculine status bestowal in which man, the father, initiates a man-to-be, his son, into the covenant with God'. Meanwhile, Israelistes (1993:37) is also aware that: 'The Jews have taken this procedure as a religious mandate and most Jews in contemporary world tend to circumcise'. Meanwhile, Waszak (1978) could not have said it better to state that:

Understanding the importance of circumcision in the religious history of Western civilization provides an insight into why the surgical procedure is still so prevalent today. Circumcision appears as a motif in the religious literature of Western civilization throughout the ages. The history of the Jewish faith can be traced through the OT by using the motif of circumcision. Some of the important theologic problems experienced in the early Christian church derived from the practice of circumcision, and the motif can be traced in the New Testament as well, especially in the writings of Paul. (p. 499)

Although circumcision is generally believed to be more prevalent among the Jews, Muslims and Orthodox Christians, a study by WHO (2007) has revealed that Christians in various other African countries also practise it. Although the debate on circumcision is gaining momentum among the Zimbabwean society in general, the practice is not emphasised among Christians in the country. However, circumcision is recommended by health practitioners for perceived therapeutic reasons as opposed to religious purity and/or rite of passage which are emphasised in both religious and cultural traditions. This anterior theory is debated in this essay. The following section looks at the cultural view of MGC with particular focus on the Karanga people of Mukandapi in Shurugwi district in southern Zimbabwe.

\section{Cultural view of male genital cutting among the Karanga people}

Shoko (2016) explains that: 'The Karanga are a group of Shona speaking people in the southern part of Zimbabwe' (pp. 501-509). Shoko's analysis resonates a study carried out by Bourdillon (1976) which extensively discussed the Shona dialectical groups in then Rhodesia (now Zimbabwe). Both Shoko and Bourdillion agree that the Shona dialectical groups comprise the following: Zezuru, Korekore, Karanga, 
Manyika, Ndau and Kalanga. According to Shoko, most of the Karanga people live in Mberengwa, Zvishavane and Shurugwi districts in the Midlands Province, as well as in Chivi and Zaka in Masvingo Province. In addition, Chiringa, Ramathuba and Mashau (2016) have also agreed that male circumcision has been practised among the Shangani in Chiredzi and Mwenezi districts and the Varemba in Gutu and Mberengwa districts for traditional purposes' (pp. 1-6).

Mandova, Mutonhori and Mudzanire (2012:318) also write that: 'Male circumcision has been widely performed on boys and young men in Africa and other parts of the world'. Common among the reasons for practising traditional male circumcision in Africa is the rite of passage to adulthood (Mwashambwa et al. 2013:3). According to Dzichauya, among the Karanga people of Mukandapi community, MGC was practised since time immemorial. Dzichauya narrates that the Mukandapi tribe regarded with high respect the sexual life particularly of their boy children when they graduated to becoming grown up men as embedded in their cultural values. Boys in their teens were considered for the rite of MGC. In order to guard against family disputes arising from sexual dysfunction of mboro (penis) (see Chabata \& Mavhu 2005:253), genital make-up of boys was usually and constantly examined. Dzichauya revealed that a boy should be examined for any genital defect at an early stage so that the community of elderly men would find a solution to a problem as the boy prepares to become an adult man.

Underneath the head of mboro, there is a tsinga [vein] which a baby boy is born with. This tsinga is the force which usually pulls the head of mboro to point downwards. Dzichauya explains that when mboro points downwards as a result of the 'pull', penetration into beche [vagina] (Chabata \& Mavhu 2005:253) is somehow disturbed. Some theories say that it is this part which shows that the virginity of a boy child is still intact. It appears that this vein tears and breaks naturally when it forces its way into the vagina during intercourse particularly with a woman who is also a virgin. In some cases, the foreskin cannot stretch full-length towards the back when this tsinga is intact. It also causes some pain when one forces the foreskin open. However, this tsinga was usually removed by elders of Mukandapi in order to allow for easy penetration of mboro into beche. My conversation which lasted over $1 \mathrm{~h}$ with Dzichauya on this subject comprised details on cultural female genital mutilation (FGM) (Ibe \& Johnson-Agbakwu 2011:28; Serour 2010:93-96) - performed on young girls as well. This study has also benefitted immensely from the finding by Hrdy (1987:1109-1119) that FGM also contributes to the epidemic of AIDS. Various theories to that finding have been advanced. However, because of limited space such a discussion will be explored in another article.

The cultural procedure on males is performed by using the long hairs at the end tassel of the cow tail. The elderly man uses one hair to tie the spot where the foreskin is attached to the underside of mboro. With time, this vein is broken and hence loosening the foreskin from under the surface of mboro leaving the glans bare. The foreskin of the penis can now be moved forth and back with ease. With constant use, the foreskin may forever not cover the head of the penis. Dzicahuya asserted that cultural elderly men believed that a mutilated mboro is preferred sexually than one whose foreskin is intact. This procedure is done in conjunction with the provision of traditional herbs meant to empower young boys as part of the preparation into manhood. The process begins with young boys who usually perform the task of heading cattle. Around noon, the boys are summoned to swimming in a river under the watchful eyes of elders. The elderly men will be watching the naked young boys in order to examine a penis with some defect. After swimming, the boys are then gathered at the beach or bank of the river where roasted nyimo [ground nuts] and chibage [mealie grain] have been prepared.

Dzichauya continues that the process commences with storytelling, especially about women and sexual intercourse. Usually, sexually active boys would have their penises erecting demonstrating their ability to penetrate a vagina and to impregnate a woman. A penis which does not respond to such stories as expected may be regarded as having some genital complications. The initial 'curing' phase begins with eating roasted nyimo or chibage by the boy with a defective penis. Information was not readily available about nutritional intake in roasted nyimo and chibage. Perhaps Ayoola, Adeyeye and Onawumi's (2012:55) explanation that 'Groundnut seed contains $44 \%$ to $56 \%$ oil and $22 \%$ to $30 \%$ protein on a dry seed basis and is a rich source of minerals $(\mathrm{P}$, $\mathrm{Ca}, \mathrm{Mg}$ and $\mathrm{K}$ ) and Vitamins (E, K and B group)' serves to suggest why ground nuts were believed to be helpful in the provision of medicinal properties for sexual enhancement by the Mukandapi community (see also Savage \& Keenan 1994:173-213).

If the Karanga people of Mukandapi discovered nyimo as being rich in enhancing sexual excitement, it demonstrates that modern dieticians would appreciate that Africa's indigenous knowledge systems (IKSs) (Owusu-Anseh \& Mji 2013:1-5) are rich in research and development (Hall 2002:35-51), with particular reference to medicinal properties capable of not only soothing but also curing ailments including genital complications. In a colonial and oppressive administration system in southern Rhodesia, IKSs would not be tolerated because it guaranteed independence and self-sustenance among Africans. As rightly remarked by Mubonderi and Rwodzi (2015:64), the white colonial administration put instruments in place to ensure that Africans remained a permanent source of cheap labour. To make sure that Africans remained loyal and controllable, African knowledge systems were neither recognised nor documented, which had a perpetually negative impact on 
traditional medicine (Waite 2000:236). Even in our postcolonial times, conventional medical practices and the church do not approve of IKSs in terms of traditional medicine. Thus, one would agree with Owusu-Anseh and Mji (2013:1) who acknowledged Ngara's (2007) study that: 'Contributions made by Africa and her people to history and civilisation are conspicuously missing from text books for formal education and generally remain unknown to many'. This systemic characterisation of African cultures and IKSs has consistently and in a sustained manner regarded African approaches of curing ailments as inferior, underdeveloped and uncivilised.

However, with particular focus on the current theme, if the abnormality of a teen with a genital problem persists, the boy may need attention by way of relevant African traditional herbs. Meanwhile, Dzicahuya maintained that the Mukandapi elders taught and warned the young boys to refrain from sexual intercourse before marriage and before lobola [bride price] is paid to the in-laws. For modern societies or anthropologists, these cultural practices may appear strange in view of HIV and AIDS prevention. However, one may also learn from the conclusions by Gausset (2001) who opines that:

Anthropologists are not supposed to be social engineers, remodelling or fighting against the culture of the people they study, but rather they should engage in a constructive dialogue in which they learn how to adapt the discourse of prevention to the local realities. (p. 517).

However, it is alleged that some cultures in southern Zimbabwe have since stopped practising MGC. Dzichauya subscribes to this notion, adding that MGC among the Mukandapi people has died a natural death, perhaps because of either infiltration by biblical teachings against traditional practices and cultural values or adaption to modern life by rural communities. The above view is held at the backdrop of a belief by some Christian groupings that African traditional herbs and African ways of dealing with ailments are evil and satanic (Rugwiji 2008:102). Chikutsa and Maharaj (2015) have also established some beliefs which suggest that circumcision maybe associated with satanic rituals (Hall 2002:35-51). Kebaabetswe et al. (2003:214-219) have reiterated that concerns about men gathering together and the possibility of uprisings motivated the abolition. One would add that imposition of biblical teachings on local communities might have led to the abolition of numerous other African cultural practices including circumcision. The following section examines the negative impact of political and socio-economic crises on HIV and AIDS in Zimbabwe.

\section{Poverty and human immunodeficiency virus and acquired immune deficiency syndrome in Zimbabwe}

HIV is the virus that causes a medical condition called AIDS. Topley (1988:842-844) acknowledges that: 'The first AIDS case was reported in Zimbabwe in 1985'. Since the late 1990s and the early 2000s, HIV and AIDS prevalence has been increasing because of poverty and starvation. Meanwhile, Mpofu (2014) asserts as follows:

Sub-Saharan Africa remains the part of the world most affected by HIV and AIDS. Zimbabwe is one of the countries worst affected by HIV and AIDS in the southern sub-region of Africa, although transmission rates have been declining in the last few years. ${ }^{4}$

Hence, the following observation by Gregson et al. (1997:1269-1280) is also in order: 'Mortality began to rise in urban areas of Zimbabwe in the late 1980s and in rural areas in the early to mid-1990s'. Rugwiji (2014), who does not present his case differently, also opines that: 'Political dynamics and socio-economic factors have contributed to the increase in HIV and AIDS cases'. Political dynamics surrounding the land question following the farm invasions of the early 2000s have had a negative impact on Zimbabwe's economic life which until to date continue to aggravate vulnerability to poverty and starvation among societies. According to Rugwiji (2013:197), poverty among Zimbabwean societies has become a cause for concern as well as a basic element of vulnerability to HIV and AIDS. Some citizens, especially the womenfolk, are reportedly opting to prostitution as a strategy towards circumventing poverty and starvation because of the high rate of unemployment and economic meltdown prevailing in the country (Chirisa \& Muchini 2011:2). The formation of an association called Commercial Sex Workers (CSW), an accomplice of the African Sex Workers Alliance (Mama 2015:132), is a desperate move by some women to engage in legalised prostitution as a survival mechanism. It is reported that in some cases, these sex workers 'agree' to unprotected sex when offered higher monetary incentive (Doezama \& Kempadoo 1999).

The Zimbabwean government (together with some humanitarian organisations) has been scaling up the fight against HIV and AIDS by employing various strategies. Ashengo et al. (2014) have confirmed that: 'Since 2009 both Tanzania and Zimbabwe have rapidly expanded voluntary medical male circumcision (VMMC) services through different delivery models (outreach or mobile)' (p. e83642). Various other campaign models including media platforms (billboards, posters, radio, Television, etc.) have been utilised extensively. All these efforts demonstrate the criticality of the fight against the epidemic. Although HIV and AIDS still claims many lives today (Rugwiji 2013:197), the advent of condoms and introduction of ARVs have provided for others a lifeline to survive longer. Faith-based organisations (FBOs) still recommend abstinence as a precautionary measure against HIV and AIDS. This recommendation has led other critical commentators such as Mapuranga (2010:13) to point out that churches have been accused of preaching the gospel of abstinence, which, with today's generation, seems to be hardly practised. The next section explains what a 'myth' is because in this essay the notion of regarding MGC as a preventive method against HIV and AIDS is critiqued as one of numerous myths.

4.For this view, see also Tsvere and Pedzisai (2014:236) 


\section{What is a myth?}

\section{A 'myth' is:}

a story, usually set in the distant past when the normal rules of physics do not apply (i.e. that world is not our world), that offers a summary of a cultural worldview. It explains how life as we know it came to be; it expresses our hopes and fears. (Knight \& Levine 2011:66-67).

According to Malan (2016:1), 'myth refers to the narrative threads from which a culture's mythology (a mythical worldview as a frame of reference) is woven'. Christine Hayes further defines myth as 'error or falsehood' (2012:5-9). Most of the myth narratives making rounds in our society usually have something to do with the curing of illnesses or as charm. A few examples will suffice. Although the drive by South Africa (and other states) to 'legalise rhino trade' (De Beer 2016:11-18) has serious implications on the rhino population, the myth that a rhino horn contains 'therapeutic and medicinal properties' (Crookes \& Blignaut 2015:11-18) has tended to promote illegal hunting and poaching. With direct reference to one of the themes under investigation, 'the virgin cleansing myth' (Leclerc-Madlala 2002:87-95) is the belief that when a HIV-positive person sleeps with a virgin, one will be cured of the virus. Hence, Leclerc-Madlala (2002:87) has further mourned: 'The belief that HIV and AIDS can be cured as a result of sex with a virgin has been identified as a possible factor in the rape of babies and children in South Africa'. The myth which continues to be popularised by some theorists and medical research claimants is that: 'MGC reduces the infection rate of HIV by at least $60 \%$ ' (Sibanda 2013:1). This myth has led to the mushrooming of initiation centres and practitioners offering circumcision services. Mpofu (2014) revealed that:

The Zimbabwean government is encouraging more men to get circumcised in an effort to fight AIDS. Scientists say MGC may reduce the transmission of the HIV virus by up to 60 percent. To date, it is estimated that close to 200,000 males have been circumcised. The Zimbabwean government officials are hopeful that their goal of 1.3 million circumcised men can be achieved.

Although government health institutions in Zimbabwe have also become initiation centres where circumcision is conducted for free - for example, Harare Central Hospital Spilhaus Family Planning Center (Mpofu 2014) - numerous procedures are not without cost. The myth has also attracted many young people to be circumcised after which some of them would indulge in unprotected sex because they have obtained some 'endorsement' that the procedure would prevent them from contracting HIV, which causes AIDS. This article attempts to demonstrate that the efforts by various stakeholders working towards the control and reduction of HIV and AIDS prevalence in the country are systemically undermined by such a myth. To my mind, the myth of a circumcised penis reducing the transmission of HIV by $60 \%$ is poised towards the escalation of the epidemic because the circumcised 'graduates' see themselves as immune to sexually related infections (SRIs). This article cautions that the myth could be one of the 'main causatives of high prevalence rates and worst impacts of HIV and AIDS in the sub-Saharan African region' (Tsodzo 2007:5). In my view, continuous awareness campaigns about the deadly virus, condom use and abstinence are preferred as options.

During the past few years, numerous research works have also been published about other 'myths' surrounding HIV and AIDS. For example, Rugwiji's (2012) publication on rape of minors revealed that HIV-infected adult males were indulging in raping babies following a myth that a vagina of a virgin girl cures the virus. Tsodzo (2007:45) has also noted that 'child sexual abuse is one of the major factors exacerbating the spread of HIV infection among children, particularly the girl-child'. Rugwiji's (2014) previous contribution also explored the widely popularised myth that circumcision enhances orgasm on both partners, arguing that this claim has proved to not be convincing. The same myth has led African women (including Zimbabweans) to practise what is technically known as 'dry sex' which comprises drying or 'tightening the vagina by various methods of douching or application of leaves and powders to absorb the vaginal lubrication' (Civic \& Wilson 1996:91-98). Tsodzo (2007) also critiqued another theory that:

People living with HIV and AIDS (PLWHA) on Anti-Retroviral Therapy (ART) who think that because they feel they have significantly recovered through the use of ARVs could suddenly go back to their old ways such as having sex with multiple partners. (p. 64)

Last is the myth advanced by some FBOs that HIV and AIDS can be cured through a religious ritual or by prayer (see Behrend 2007:41; 2009:35). To date, evidence is scanty about PLWHA who have been cured of the deadly virus in contrast to numerous claims about divine healing. Such claims are made at the backdrop of criticism by some section of society against the church for being inactive and silent about the epidemic (Mapuranga 2010:13). There is also 'the medical myth that infants do not feel pain' (Narulla 2007:100) as a result of circumcision. Several formal and informal conversations on circumcision seem to suggest that the circumcised graduate endures extreme pain.

It is believed that for hygienic purposes, circumcision was necessary in the ancient Near Eastern world because of infections initiated by the aggravation of dirt and sand under the foreskin where it was difficult for men to achieve sanitation, particularly those engaged in a prolonged battle. Clifford (1893) writes that: 'During the 20th century MGC gained popularity for perceived health benefits and social reasons in North America, New Zealand and Europe'. Soilleux and Coleman (2004:77-78) have affirmed that: 'It is maintained that because the inner part of the foreskin contains many special immunological cells it becomes a prime target for HIV'. Perhaps, the notion of circumcision as a preventive method against HIV and AIDS might have developed in our modern post-biblical world from such theories. However, the Council on Scientific Affairs of the American Medical Association (CSAAMA) (1999) argues that 
MGC is a non-therapeutic procedure. Evidence shows that when MGC was first introduced, 'It was practised on sociocultural grounds with little medical or public health justification' (CSAAMA 1999). Calvin Gwendume also argues that 'the use of medical male circumcision to prevent HIV infection in sub-Saharan Africa can result in ethical dilemmas for health educators and uncertainty among participants' (2011:89-94).

\section{Conclusion}

The main purpose of this article was to problematise circumcision in the biblical text and to demystify the myth that MGC can be relied upon as a preventive method against HIV and AIDS in Zimbabwe. The article demonstrated with examples from religious and biblical perspectives, citing Israelite practice of circumcision as a rite of passage in which a boy child was prepared for entry into manhood. It was argued that circumcision began as a religious (biblical) and cultural initiation procedure. Solution to health complications was not the original intent of circumcision among societies in ancient Israel. Male genital cutting among the Karanga people of Mukandapi in rural Shurugwi - northwest of the city of Gweru in the Midlands Province of Zimbabwe - was also examined. The study has shown that MGC was already practised by the Mukandapi tribe in Shurugwi since ancient times for different reasons other than the popular myth that circumcision reduces the transmission of sexually transmitted illnesses (STIs) including HIV. It was argued that the Karanga people performed MGC to prepare a boy child for manhood and for his sexual relationship when married. The article critiqued not only as misleading the claim by some section of the medical fraternity that circumcision provides for $60 \%$ chance of circumventing HIV and AIDS but also that it provides for those who are circumcised an endorsement to continue engaging in unprotected sex.

The conventional research finding currently held by reputable medical associations the world over is that medicine to cure HIV and AIDS has not been found yet. Medical scientists have argued that MGC is not performed routinely for any medical condition. A study by Phillip Mateveke, Dominic Mashoko and Achievement Mateveke has shown that among the dangers of male circumcision from recent research in South Africa, promiscuity was being cited (2012:253). In my view, the notion among modern societies that circumcision serves as a preventive method against STIs and other viruses such as HIV attempts not only to trivialise the risks associated with the epidemic but also to disenfranchise the origin of circumcision in view of religious (biblical) and cultural contexts. Meanwhile, protection is recommended through abstinence and the use of condoms. Those on ART should continue taking their drugs as recommended for their own continued survival.

\section{Recommendations}

In the final analysis, this article makes the following recommendations:
- It has been proved that MGC cannot be performed for therapeutic advantages. The study complements the latest finding by those in the medical field and conclusions by renowned scholars which critique the claim that circumcision prevents HIV. Such a claim has repeatedly been proven to be exaggerated. Chikutsa, Ncube and Mutsau have reiterated that such a notion 'could lead to a false sense of effective protection against HIV' (2013:5).

- Consistent information dissemination on HIV and AIDS should be intensified. The belief that circumcised people may not contract the virus attempts to undermine all efforts earmarked towards reducing the prevalence of the epidemic. Such a section of society is potentially at risk of contracting and transmitting the deadly virus when exposed to unprotected sex. The majority view is that abstinence and/or the use of condoms can prevent the spread of STIs, including HIV and AIDS. Chikutsa and Maharaj (2015) also concurred that:

There is an urgent need for the development of communications that directly address the misconceptions about voluntary medical MGC, adding that communication should encourage circumcised men to continue using condoms. (p. 603)

- Continued awareness campaign is required on the part of society recommending circumcision procedure (if necessary) to be performed by a medical professional in a clinical setup as opposed to 'a traditional/religious provider in a nonmedical environment' (AAP 2012:760). Among some traditional communities, MGC is promulgated by unscrupulous individuals, because the financial aspect is involved (Hatzold et al. 2014:4). In numerous cases, people are allegedly known to be paying money for the procedure (Rugwiji 2014). In Zimbabwe, government health institutions are encouraging circumcision by performing the procedure for free.

- It is in the best interest of the parent to ascertain whether it is necessary to have their child circumcised. Adequate information is required in this regard. In my view, taking cognizance of the pain endured when one is circumcised, I do not see immediate health benefits which derive from circumcising a young boy as is happening in some cases, especially in view of HIV and AIDS prevention.

- HIV and AIDS are aggravated by poverty because of political instability and socio-economic crises in Zimbabwe. Even efforts towards assisting PLWHA and affected communities are stalled by lack of resources because of socio-economic crises. The Zimbabwean leadership should work towards poverty alleviation as a priority.

- The church should be assertive of its role as the voice of the voiceless (Rugwiji 2013:231). However, I would like to concur with Pastor Lawrence Mogoera who, in his sermon, preached about aggressive faith. ${ }^{5}$ According to him, aggressive faith consists of praying, taking action and getting involved in disciplines such as politics and HIV and AIDS prevention which because of stereotypes

5.This assertion comes out of an observation in church when Pastor Lawrence Mogoera was preaching at Rock of Ages Baptist Church in Lotus Gardens, Pretoria, South Africa, Sunday, 25 September 2016. 
were traditionally regarded as preserves of seasoned political antagonists, HIV and AIDS experts as well as health practitioners. Believing communities must speak and be heard condemning injustice and corruption, as well as recommending implementation of strategies towards poverty reduction. Although HIV and AIDS are also affecting the affluent, they are devastating the poor worst. Usually, the poor have 'no voice'. ${ }^{6}$

\section{Acknowledgements Competing interests}

The author declares that he has no financial or personal relationships which may have inappropriately influenced him in writing this article.

\section{References}

AAP, 2012, 'Technical Report: Male circumcision', Pediatrics 130(3), 756-785. https:// doi.org/10.1542/peds.2012-1990

www.pediatrics.org/cgi/doi/10.1542/peds.2012-1990 doi:10.1542/peds.2012-1990

Ashengo, T.A., Hatzold, K., Mahler, H., Rock, A., Kanagat, N., Magalona, S. et al., 2014, 'Voluntary medical male circumcision (VMMC) in Tanzania and Zimbabwe: Service delivery intensity and modality and their influence on the age of clients', PLOS One 9(5), e83642. https://doi.org/10.1371/journal.pone.0083642

Ayoola, P.B., Adeyeye, A. \& Onawumi, O.O., 2012, 'Chemical evaluation of food value of groundnut (Arachi hypogaea) seeds', American Journal of Food and Nutrition 2(3), 55-57. https://doi.org/10.5251/ajfn.2012.2.3.55.57

Behrend, H., 2007, 'The rise of occult powers, AIDS and the Roman Catholic Church in Western Uganda', Journal of Religion in Africa 37(1), 41-58. https://doi.org/ $10.1163 / 157006607 \times 166582$

Behrend, H., 2009, 'The rise of occult powers, AIDS and the Roman Catholic Church in Western Uganda', in F. Becker \& P.W. Geissler (eds.), AIDS and religious practice in Africa, pp. 27-47, Brill, Leiden.

Bourdillon, M.F.C., 1976, The Shona people: Ethnography of the contemporary Shona with special reference to their religion, Mambo Press, Gweru.

Cecula, N., 2016, 'Deuteronomy 10:16 in discourse with Xhosa ritual circumcision' A Paper Presented at the IOSOT Congress at Stellenbosch University, Stellenbosch University, South Africa, 4-9th September.

Chabata, E. \& Mavhu, W.M., 2005, 'To call or not to call a spade a spade: The dilemma of treating "offensive" Terms in Duramazwi Guru ReChiShona', Lexikos 15 253-264.

Chikutsa, A. \& Maharaj, P., 2015, 'Social representations of male circumcision as prophylaxis against HIV and AIDS in Zimbabwe', BMC Public Health 15, 603. prophylaxis against HIV and AlDS in Zimbab

Chikutsa, A., Ncube, A.C. \& Mutsau, S., 2013, Male circumcision and risky sexual behaviour in Zimbabwe: Evidence from the 2010-11 Zimbabwe demographic and health survey, ICF International, Calverton, MD.

Chiringa, I.O., Ramathuba, D.U. \& Mashau, N.S., 2016, 'Factors contributing to the low uptake of medical male circumcision in Mutare Rural District, Zimbabwe', African Journal of Primary Health Care \& Family Medicine 8(2), 1-6. https://doi.org/ 10.4102/phcfm.v8i2.966

Chirisa, I. \& Muchini, T., 2011, 'Youth, unemployment and peri-urbanity in Zimbabwe: A snapshot of lessons from Hatcliffe', International Journal of Politics and Good Governance 2(2.2), 1-15.

Civic, D. \& Wilson, D., 1996, 'Dry sex in Zimbabwe and implications for condom use', Socia Science \& Medicine 42(1), 91-98. https://doi.org/10.1016/0277-9536(95)00081-X

Clifford, M., 1893, Circumcision: Its advantages and how to perform it, J. \& A. Churchill, London.

Crookes, D.J. \& Blignaut, J.N., 2015, 'Debunking the myth that a legal trade will solve the rhino crisis: A system dynamics model for market demand', Journal of Nature Conservation 28, 11-28. https://doi.org/10.1016/j.jnc.2015.08.001

CSAAMA, 1999, Neonatal circumcision report 10, American Medical Association, Chicago, IL.

De Beer, W., 2016, 'The viability of legalising international trade in rhino horn and the possible effect on rhino poaching in South Africa', PhD thesis, University of South Africa, Pretoria, viewed 18 August 2017, from http://hdl.handle.net/10500/22651

De Vaux, R., 1978, The early history of Israel, Westminster, Philadelphia, PA.

6.By 'no voice', reference is made to an individual who has deliberately been incapacitated to speak because of impoverishment. Such a person is dependent on incapacitated to speak because of impoverishment. Such a person is dependent on the oppressor who apparently sustains their arrogance and would want to see them and 'humble' because their poverty incapacitates them to complain against injustice and 'humble' because their poverty incapacitates them to complain against injustice for fear that they will lose even the
takes advantage of such a scenario.
Doezama, J. \& Kempadoo, K., 1999, Global sex workers, Routledge, New York.

Gausset, Q., 2001, 'AIDS and cultural practices in Africa: The case of the Tonga (Zambia)', Social Science and Medicine 52, 509-518. https://doi.org/10.1016/ S0277-9536(00)00156-8

Glass, J.M., 1999, 'Religious circumcision: A Jewish view', BJU International 83, 17-21. https://doi.org/10.1046/j.1464-410x.1999.0830s1017.x

Goldingay, J., 2000, 'The significance of circumcision', Journal for the Study of the Old Testament 88, 3-18. https://doi.org/10.1177/030908920002508801

Gregson, S., Anderson, R.M., Ndlovu, J., Zhuwawu, T. \& Chandiwana, S.K., 1997, 'Recent upturn in mortality in rural Zimbabwe: Evidence for an early demographic
impact of HIV-1 infection?', AIDS 11(10), 1269-1280. https://doi.org/10.1097/ impact of HIV-1 infection?',

Gwendume, C., 2011, 'The ethical concerns of using medical male circumcision in HIV prevention in sub-Saharan Africa', SAJBL 4(2), 89-94.

Hall, B.H., 2002, 'The financing of research and development', Oxford Review of Economic Policy 18(1), 35-51. https://doi.org/10.1093/oxrep/18.1.35

Hatzold, K., Mavhu, W., Jasi, P., Chatora, K., Cowan, F.M., Taruberekera, N. et al., 2014 'Barriers and motivators to voluntary medical male circumcision uptake among
different age groups of men in Zimbabwe: Results from a mixed methods study', PLoS One 9(5), e85051. https://doi.org/10.1371/journal.pone.0085051

Hayes, C., 2012, Introduction to the Bible, Yale University Press, New Haven, CT.

Hoffman, L.A., 1996, Covenant of blood, University of Chicago, Chicago, IL.

Hrdy, D.B., 1987, 'Cultural practices contributing to the transmission of human immunodeficiency virus in Africa', Reviews of Infectious Diseases 9(6), 1109-1119. https://doi.org/10.1093/clinids/9.6.1109

Ibe, C. \& Johnson-Agbakwu, C., 2011, 'Female genital cutting: Addressing the issues of culture and ethics', The Female Patient 36, 28-31.

Israelistes, J.P., 1993, A history of the Jews, Phoenix Press, London.

Kebaabetswe, P., Lockman, S., Mogwe, S., Mandevu, R., Thior, I., Essex, M. et al., 2003, 'Male circumcision: An acceptable strategy for HIV prevention in Botswana', Sexually Transmitted Infections 79, 214-219. https://doi.org/10.1136/sti.79.3.214

Knight, D.A. \& Levine, A.-J., 2011, The meaning of the Bible: What the Jewish Scriptures and Christian Old Testament can teach us, HarperCollins, New York.

Leclerc-Madlala, S., 2002, 'On the virgin cleansing myth: Gendered bodies: AIDS and ethnomedicine', African Journal of AIDS Research 1, 87-95. https://doi.org/10.29 89/16085906.2002.9626548

Malan, G., 2016, 'Myth as a metaphor', HTS Theological Studies 72(4), 1-8. https:// doi.org/10.4102/hts.v72i4.3260

Mama, A., 2015, Feminist Africa: Feminism and Pan-Africanism. Issue 20, African Gender Institute, Cape Town.

Mandova, E., Mutonhori, T. \& Mudzanire, S., 2012, 'An analysis of HOKO as knowledge systems', International Journal of Academic Research in Progressive Education Development 1(4), 318-325.

Mapuranga, T.P., 2010, 'A phenomenological investigation into the effects of traditional beliefs and practices on women and HIV and AIDS with special reference to Chipinge, Zimbabwe', PhD thesis, Faculty of Arts, Department of Religious Studies, Classics and Philosophy, University of Zimbabwe, Harare.

Mararike, C., 2010, 'Bottom-up approaches and organic program development fundamentals', Class Lecture, University of Zimbabwe, Harare, 28th May.

Mateveke, P., Mashoko, D. \& Mateveke, A., 2012, 'Perceptions of people towards male circumcision as a technical method to reduce HIV and AIDS infection in Masvingo District of Zimbabwe', Journal of AIDS and HIV Research 4(11), 248-255.

Meade, J.D., 2016, 'The meaning of circumcision in Israel: A proposal for a transfer of rite from Egypt to Israel', SBJT 20(1), 35-54.

Mogoera, L., 2016, Aggressive faith: Sermon, Rock of Ages Baptist Church, Lotus Gardens, Pretoria.

Mpofu, S., 2014, 'Zimbabwe urges male circumcision to reduce HIV and AIDS', The Voice of America, viewed 18 March 2017, from http://www.voanews.com/a/zimbabweurges-male-circumcision-to-reduce-hiv-aids-transmission/1853121.html

Mubonderi, B. \& Rwodzi, A., 2015, 'Implications of the colonial legacy on the prospects and future of entrepreneurship in Zimbabwe', IOSR Journal of Humanities and Social Science 20(11), 64-70.

Mwashambwa, Y.M., Mwampagatwa, I.H., Rastegaev, A. \& Gesase, A.P., 2013, 'The male circumcision: The oldest ancient procedure, its past, present and future roles', Tanzania Journal of Health Research 15(3), 199-204. https://doi. org/10.4314/thrb.v15i3.8

Narulla, R., 2007, 'Circumscribing circumcision: Traversing the moral and legal ground around a hidden human rights violation', Australian Journal of Human Rights 12(2), 89-118, viewed 23 September 2017, from http://www.austlii.edu.au/au/ journals/AJHR/2007/24.pdf

Ngara, C., 2007, 'African ways of knowing and pedagogy revisited', Journal of Contemporary Issues in Education 2(2), 7-20.

Owusu-Anseh, F.E. \& Mji, G., 2013, 'African indigenous knowledge and research', African Journal of Disability 2(1), 1-5. https://doi.org/10.4102/ajod.v2i1.30

Papu, J. \& Verster, P., 2006, 'A biblical, cultural and missiological critique of traditional circumcision among Xhosa-speaking Christians', Acta Theologica 2, 178-198.

Plaskow, J., 1991, Standing again at Sinai, Harper, San Francisco, CA.

Rugwiji, T., 2008, 'Reading the exodus tradition from a Zimbabwean perspective', MA dissertation, Department of Biblical and Ancient Studies, University of South Africa, Pretoria. 
Rugwiji, T., 2012, 'Reading the David-Mephibosheth narrative from a pastora hermeneutical perspective: A social model', Scriptura 109, 82-95. https://doi. org/10.7833/109-0-126

Rugwiji, T., 2013, 'Appropriating Judean postexilic literature in a postcolonia discourse: A case for Zimbabwe', PhD thesis, Department of Biblical and Ancient Studies, University of South Africa, Pretoria.

Rugwiji, T., 2014, 'Rereading circumcision as an identity marker (Gn 17:9-14) Contemporary perspectives on male genital mutilation amongst Xhosa communities in South Africa', Journal for Semitics 23(1), 237-263. https://doi. org/10.25159/1013-8471/2813

Savage, G.P. \& Keenan, J.I., 1994, 'The composition and nutritive value of groundnut kernels', in J. Smart (ed.), The groundnut crop: Scientific basis for improvement, pp. 173-213, Chapman and Hall, London.

Serour, G.I., 2010, 'The issue of re-infibulation', International Journal of Gynecology \& Obstetrics 109(2), 93-96. https://doi.org/10.1016/j.ijgo.2010.01.001

Shoko, T., 2016, 'Karanga traditional medicine and healing', AJTCAM 4(4), 501-509. https://doi.org/10.4314/ajtcam.v4i4.31244

Sibanda, F., 2013, 'Beyond identity scars: Reflections on the vitality of Shangani male circumcision in the context of HIV AND AIDSin Zimbabwe', Journal of Emerging Trends in Educational Research and Policy Studies 4(1), 1-7.

Soilleux, E.J. \& Coleman, N., 2004, 'Expression of DC-SIGN in human foreskin may facilitate sexual transmission of HIV', Journal of Clinical Pathology 57, 77-78. https://doi.org/10.1136/jcp.57.1.77
Taddio, A., Katz, J., llersich, A.L. \& Koren, G., 1997, 'Effect of neonatal circumcision on pain response during subsequent routine vaccination', Lancet 349, 599-603. https://doi.org/10.1016/S0140-6736(96)10316-0

Topley, J.M., 1988, 'HIV infection in Zimbabwe,' Archives of Disease in Childhood 63(7) 842-844. https://doi.org/10.1136/adc.63.7.842

Tsodzo, C.C., 2007, 'The challenges of the HIV and AIDS pandemic among informal settlements - A case study of Hatcliffe Extension in Harare, Zimbabwe', Master of Philosophy dissertation, University of Zimbabwe, Harare.

Tsvere, M. \& and Pedzisai, C., 2014, 'Attitudes of University students towards male circumcision', International Journal of Innovative Research \& Development 3(2), 236-242.

Waite, G., 2000, 'Traditional medicine and the quest for national identity in Zimbabwe', Zambezia XXVII(II), 235-268. https://doi.org/10.4314/zjh.v27i2.6752

Waszak, S.J., 1978, 'The historic significance of circumcision', Obstetrics and Gynecology 51(4), 499-501. https://doi.org/10.1097/00006250-197804000-00023

Wiswell, T.E., Miller, G.M., Gelston, H.M., Jr., Jones, S.K. \& Clemmings, A.F., 1988 'Effect of circumcision status on periurethral bacterial flora during the first year of life', Journal of Pediatrics 113(3), 442-446. https://doi.org/10.1016/S00223476(88)80625-5

WHO, 2007, Male circumcision: Global trends and determinants of prevalence, safety and acceptability, WHO Press, Geneva. 